\title{
The Influence of Rose All Day Instagram Sales Promotion Message And Endorsement By Beauty Influencer on Followers' Buying Intention
}

\author{
Jessica Aisyah Larasati ${ }^{1}$, Daniel Susilo ${ }^{2 *}$ \\ ${ }^{12}$ School of Strategic Communication, Universitas Multimedia Nusantara \\ *Email: daniel.susilo@umn.ac.id
}

\begin{abstract}
Abstrak
Penelitian ini terbentuk karena maraknya penggunaan pemasaran media sosial melalui Instagram yang juga dipilih oleh merek Rose All Day Cosmetics, salah satu perusahaan kosmetik lokal. Penelitian ini bertujuan untuk mengetahui pengaruh daya tarik pesan promosi penjualan di Instagram Rose All Day Cosmetics dan endorsement oleh beauty influencer baik secara simultan maupun secara parsial terhadap minat beli followers. Teori yang digunakan dalam penelitian ini adalah teori Elaboration Likelihood Model. Adapun konsep lain dalam penelitian ini yaitu konsep daya tarik pesan, endorsement, dan minat beli. Jenis penelitian ini adalah eksplanatif dengan pendekatan kuantitatif dan metode penelitian survei. Kuesioner diperoleh secara online menggunakan fitur direct message di Instagram. Teknik pengambilan sampel dalam penelitian ini adalah non-probability sampling berupa purposive sampling sebanyak 398 responden yang ditentukan menggunakan rumus Yamane. Teknik analisis data dalam penelitian ini adalah uji regresi linear berganda. Temuan penelitian ini yaitu bahwa variabel daya tarik pesan promosi penjualan dan endorsement memiliki pengaruh terhadap minat beli pengikut baik secara parsial maupun secara simultan, dengan pengaruh simultan terhadap minat beli pengikut sebesar 51,3\%. Berdasarkan temuan tersebut, perusahaan harus melanjutkan penggunaan influencers, utamanya mikro-influencer.
\end{abstract}

Kata Kunci: Daya Tarik Pesan, Endorsement, Influencer, Minat Beli, Pesan Promosi Penjualan

\begin{abstract}
This research was conducted due to the widespread use of social media as a marketing tool in Indonesia. This phenomenon has led to a social media marketing strategy through Instagram, one of the social media platforms used by a local cosmetic company called Rose All Day Cosmetics. This study aimed to determine the effect of the attractiveness of sales promotion messages on Rose All Day Cosmetics' Instagram account and endorsement by beauty influencers on followers' buying intention. The theories used in this research were the Elaboration Likelihood Model, the attractiveness of promotional messages, endorsement, and purchase interest theory. This research was quantitative explanative research through an online survey distributed using the direct message feature on Instagram to 398 respondents previously determined by the Yamane formula. The data obtained were tested with multiple linear regression. The findings indicated that each variable significantly influences the followers' buying intention partially or simultaneously, with a simultaneous effect of as much as 51,3\% impact degree. The company must continue to follow the development of influencers, especially in the realm of micro-influencers
\end{abstract}

Keywords: Message Attractiveness, Endorsements, Influencers, Buying Interest, Sales Promotion Message 


\section{INTRODUCTION}

In the industrial revolution 4.0 towards Society 5.0, a transition took place within the marketing industry. This is a transition from traditional marketing to digital marketing, Butow et al. (2020) stated in "Ultimate Guide to Social Media Marketing." In the past, brands did a vertical process called 'Segmenting, Targeting, and Positioning' (or STP) to determine their audience. Now, such a process has transformed into a horizontal one. A brand has to gain permission from the consumer beforehand to deliver a promotional message or advertisement (De Leon et al. 2020; Kotler et al. 2017; Panuju et al.).

The transition from traditional marketing to digital marketing is supported by technological developments, especially the internet and social media (Butow et al. 2020; Riyadi et al. 2019). According to data released by We Are Social (Kemp, 2021), there is an increase in internet users from the previous year, as many as 27 million users or a $16 \%$ increase. With 170 million social media users, Instagram occupies the third position in the most used social media with $86.6 \%$. The same data shows that social media users have increased by 10 million, or a $6.3 \%$ increase compared to 2020 (Kemp, 2021). According to Butow et al. (2020), Instagram has specific advantages, including the home page, Instagram Story, and IGTV. The application that started as a platform for uploading photos from personal accounts by Kevin Systrom in 2012 has now transitioned into a business platform (Decker, 2017). Social media is an online communication and voting tool driven by conversation, user involvement, and participation (Daniel Susilo, 2021a, 2021b). Meanwhile, social media marketing can be defined as all forms of marketing consisting of direct or indirect communication, used to make actions for brands, businesses, or individuals to build awareness and recognition of the brand, business, or individual (Gunelius, 2010).

Furthermore, the cosmetic industry in Indonesia is experiencing rapid development due to the increasing number of users and makeup enthusiasts. This development encourages the improvement of the beauty industry, as stated by the Ministry of Industry of the Republic of Indonesia (Kemenperin.go.id, 2018). The national cosmetic industry noted a rapid growth compared to 2017, or a $20 \%$ growth in 2018. Rose All Day Cosmetics is one of the 153 new local beauty companies established in 2017 in Indonesia.

A similar study by Geraldine (2019) entitled "The Effect of Attractiveness of Content Social Media Marketing Instagram NKCTHI Book (Nanti Kita Cerita Tentang Hari Ini) on Consumer Purchase Intention" shows a significant effect of content attractiveness on consumer purchase intention with 54,2\% impact degree. Another study by Patricia (2018) entitled "The Effect of Endorsement by Beauty Influencers on Purchase Intention of Maybelline New York Products (Survey in Tangerang City Area)" shows that there is a $61,4 \%$ significance in endorsement by beauty influencers strategy towards customer's purchase intention.

The uniqueness of the current study lies in combining two important social media marketing strategies used in the previous studies, the attractiveness of sales promotion content and endorsement by beauty influencers. Regarding the Instagram social media marketing strategy by the Rose All Day brand, it can be seen that the main media used are the website and Instagram account. Instagram content carried out by the local cosmetic brand must continue to adapt to the internet trend development and social media usage, not only in 
Indonesia but throughout the world. Therefore, this research aimed to study the attractiveness of sales promotion messages of the Rose All Day Cosmetics Instagram account and endorsement strategy on followers' buying intention. Based on that purpose, the study proposed the following hypotheses:

Ho1: There is no effect of the attractiveness of Rose All Day's Instagram sales promotion messages and endorsement activities by beauty influencers simultaneously on followers' buying interest.

Ha1: There is an effect of the attractiveness of Rose All Day Instagram sales promotion messages and endorsement activities by beauty influencers simultaneously on followers' buying interest

Ho2: There is no effect of the attractiveness of Rose All Day Instagram sales promotion messages and endorsement activities by beauty influencers partially on followers' buying interest

Ha2: There is a partial effect of the attractiveness of Rose All Day Instagram sales promotion messages and endorsement activities by beauty influencers on followers' buying interest

Sales promotion is part of persuasive communication in a promotion. Promotion is defined as an effort to build a persuasive information channel to increase sales of goods, services, and even an idea (Belch \& Belch, 2017). Sales promotion is divided into two categories: monetary and non-monetary. The monetary promotion offers price reduction, which can be implemented through discounts, cashback, or rebates. In comparison, nonmonetary promotions offer additional value and price reductions to attract consumers, such as bonus packs, bundling, free gift with purchase, sampling, and embedded premiums (Ogden-Barnes \& Minahan, 2015). Rose All Day Cosmetic implements a mix of both sales' promotion types into their Instagram account by holding giveaways and reminding their followers of available discounts.

Petty et al. (1986) created a theory called the Elaboration Likelihood Model. This theory believed that consumers go through two main routes to make a purchase decision. The routes are the central route and peripheral route. The central route focuses on the consumer's rational and critical thinking behaviour. On the other hand, the peripheral route refers to the consumer's emotion in making a purchase decision (Griffin et al., 2015). The current study intends to analyse consumer's process in receiving Instagram promotional and endorsed content by using the Elaboration Likelihood Model. Meanwhile, the attractiveness of sales promotion message can be determined by eight dimensions (Duncan, 2005), which includes:

1. Generic offers general product information to increase the general knowledge of the products offered.

2. Pre-emptive highlights the advantages of information, event or phenomenon associated with the product compared to other information, events or phenomena in conveying a message.

3. Informational provides main information about an event or phenomenon associated with the product in conveying a message. 
4. Emotion prioritises feelings that can trigger and create a relationship between a brand and consumer in conveying a message.

5. Association creates a relationship or establishes a psychological rope between the brand and consumers, such as the brand image or the influencer used by the brand.

6. Lifestyle takes advantage of everyday phenomena by using familiar symbols to create relationships with these consumers.

7. Reminder is the use of various creative and effective ways to maintain the brand's position as a top-of-mind, without forgetting other goals such as increasing sales.

8. Interactive is a two-way communication line between consumers and the brand and provokes feedbacks or responses.

This study used six out of the eight dimensions, except for lifestyle and association. Another variable used in this research was endorsement theory by Shimp \& Andrews (2013) called the TEARS model (Trustworthiness, Expertise, Attractiveness, Respect, Similarity). Figure 1 shows the endorsement's source and receiver process in communication.

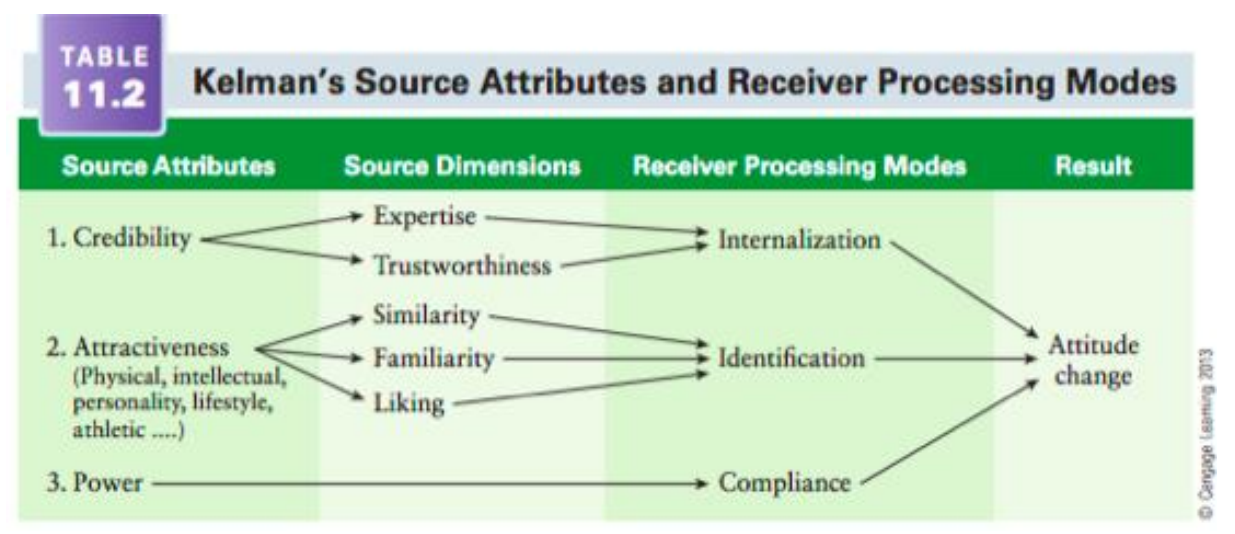

Figure 1: Kelman's Source Attributes \& Receiver Processing Modes (Shimp \& Andrews, 2013)

The variables mentioned were used to determine their impact on customer's purchase intention. According to Peter et al. (2009), purchase interest is a customer's decision making and intention to buy certain products or services. According to Ferdinand (2014), there are several indicators to identify buying interest:

1. Exploratory Interest describes the behaviour of someone with high curiosity. This high curiosity then encourages them to continue exploring information about the product or service they want to choose to have sufficient information to support their purchasing activities.

2. Preferential Interest is the desire of consumers to choose a particular brand or product over other brands or products offered in the same category or sector.

3. Transactional interest is the behaviour of a person to purchase a product or service selected after having supporting information or other external supporting factors that are sufficient to stimulate product purchasing activities from the brand.

4. Referential Interest is the behaviour of a person in sharing information about products, services or brands after purchasing the selected brand. It is possible to share the good 
experiences they have experienced during the product purchase process or the good effects that occur after using the product or service

This study focused on the attractiveness of sales promotion messages for the Rose All Day Cosmetics Instagram account and the use of endorsements by beauty influencers towards the effect on followers' buying interest, either simultaneously or partially. Therefore, figure 2 presents the framework used in this research.

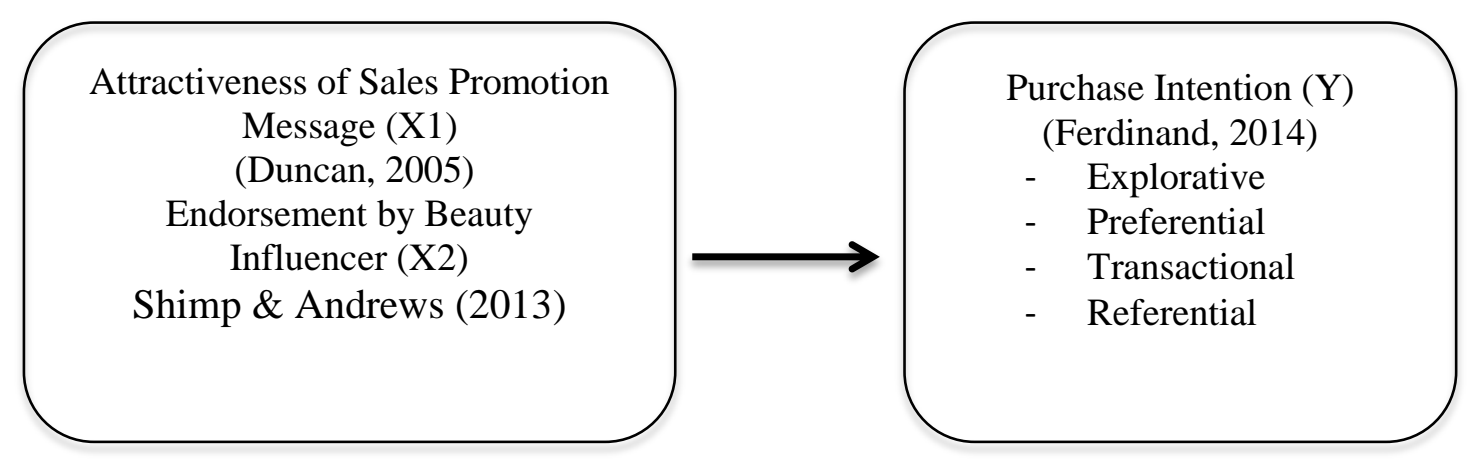

Figure 2. Conceptual Framework

\section{METHOD}

The author used a positivistic paradigm to see a phenomenon resulting from cause and effect in this study. This research uses a quantitative approach with the nature of explanatory research. According to Kriyantono (2014), researchers need an initial guess or hypothesis about a causal relationship between two or more variables in the explanatory survey method. This process is carried out because explanatory research is comparative and correlational research. To collect data, this study used an explanatory survey method. In this method, a survey is used to describe situations and phenomena in the population and find out the reasons for a situation, phenomenon or condition. It also studies the determining factor in a situation or phenomenon (Kriyantono, 2014).

Determining the population is essential in conducting a survey. The research population is the overall scope of the research object to be studied (Kriyantono, 2014). The population in this study were the followers of the Rose All Day Instagram account. As of 1 October 2021, there were 102,000 accounts following the Rose All Day Instagram account. Furthermore, the sampling was done by purposive sampling. Purposive sampling is a sampling technique of data sources with certain considerations (Sugiyono, 2018). This study used these criteria for sampling: respondents must be aged 17-45 years old, must be a Rose All Day consumer, has Instagram and follows the Rose All Day account, have been exposed to sales promotion messages from Rose All Day's Instagram account in the last five months, and have seen the Rose All Day endorsement by a beauty influencer on Instagram.

Purposive sampling was carried out so that data collection could be more focused on the research criteria mentioned above. The Yamane formula was used to determine the number of samples because this study has a large population. According to Kriyantono 
(2014), the Yamane formula is suitable for studies with a large population to estimate. The Yamane formula used to determine the sample of this study were:

$$
\begin{gathered}
N=\frac{N}{N d^{2}+1} \\
N=\frac{102 \cdot 000}{\left(102 \cdot 000 \cdot(0,05)^{2}\right)+1} \\
N=\frac{102 \cdot 000}{(102.000 \cdot 0,0025)+1} \\
N=\frac{102.000}{256}=398,437
\end{gathered}
$$

Based on the results of the Yamane formula, it was concluded that the number of samples in the study should be 398 respondents. There were two types of data used in this study, including primary data and secondary data. According to Sugiyono (2016), primary data is data obtained organically or directly without intermediaries from the research object. The primary data in this study were obtained from distributing questionnaires to predetermined respondents, namely followers of the Rose All Day Instagram account. In contrast, the secondary data were obtained from various sources, namely books and e-books, journals, and other literature, to support the statements in this study. Before the questionnaire was distributed, it went through validity and reliability tests. The validity test is crucial in developing a questionnaire for a study because the test results can determine the suitability of the question with the research (Kriyantono, 2014). In this study, the validity test was used to see the effect of the attractiveness of Rose All Day's sales promotion messages through Instagram and endorsements by beauty influencers on buying interest. In measuring the question's validity level, this research used Statistics for Social Science (SPSS) version 26 for Macintosh to analyse the Pearson Correlation number per questionnaire item. SPSS was also used to determine the reliability of the questionnaire by the Alpha Cronbach value. The Pearson Product Moment correlation formula was the basis for calculations in this validity test through the correlation of the score of each question item with the total score of the related variables. Based on the SPSS testing results for validity and reliability, the data used in the questionnaire for this study showed a valid and reliable result.

Furthermore, after getting the results of the questionnaire data, several tests were carried out. The first test was the normality test to determine the level of data distribution normality (Ghozali, 2013). In addition, a multiple regression test was carried out to find the form of equality in the relations between two or more variables. It was done to distinguish between the dependent and independent variables. The purpose of multiple regression analysis in this study was to determine the effect of the attractiveness of sales promotion messages in the Rose All Day Instagram account and endorsements by beauty influencers on the buying interest of Rose All Day Instagram followers. Multiple linear regression equation was formulated as follows.

$$
Y=\alpha+\beta 1+\beta 2 X 2+\beta n X n+e
$$




\section{RESULTS}

Based on the data from 398 questionnaires distributed to the Rose All Day Instagram account followers, we found several characteristics. The data revealed that most of the respondents $(73,6 \%)$ were female, and only $26,4 \%$ were male. Most of the respondents were aged between 17-25 years old; thus, most were still studying at the university level.

\section{The Attractiveness of Rose All Day Instagram Sales Promotion Message (X1)}

In this study, the attractiveness of sales promotion messages in discounts and giveaways is the $\mathrm{X} 1$ or the first independent variable. There are eight dimensions in the message attractiveness variables. However, this study only used six dimensions in the questionnaire. These dimensions included generic, pre-emptive, informational, emotional, reminder, and interactive. The following are the results of the study of the message attractiveness variable:

\section{Generic Dimension}

The generic dimension of the message attractiveness variable indicates that the sales promotion content in the @ roseallday.co Instagram account displays product descriptions in general. It was found that the @ roseallday.co account displays local cosmetics and that it includes a general description of Rose All Day Cosmetics products. A convincing number of respondents agreed with the statement, proving that the @ roseallday.co account has clearly displayed general product descriptions for its followers.

\section{Pre-emptive Dimension}

The pre-emptive dimension is a message dimension that shows the differences and uniqueness of the product compared to other products in the same category. Based on the response of Rose All Day Instagram followers, it can be concluded that the @ roseallday.co account has highlighted the uniqueness of the product in its content, namely the concept of natural cosmetics or better known as "No Makeup Look"

\section{Informational Dimension}

The informational dimension is the essence of a sales promotion message or an event and phenomenon associated with the product. Based on the data obtained by the questionnaire, more than $88 \%$ of respondents consider the content of the @ roseallday.co account to be quite informative about the ongoing giveaway contest and the brand's current promotional activities, such as discounts.

\section{Emotional Dimension}

The emotional dimension refers to the emotional impact of a message. The data revealed that respondents feel that the giveaway from the @ roseallday.co account is one of the most persuasive contents because it invited the consumers to show products that they have purchased. Indirectly, the company also invites consumers to promote the product and provide testimony for those who have never tried Rose All Day Cosmetics products. Therefore, the brand gains new customers while retaining old customers, which in general can increase product purchases. 


\section{Reminder Dimension}

The reminder dimension in the message attractiveness variable is the nature of the reminder of the information in the message. In this study, the author connected the reminder dimension to the content of reminders for discounts and giveaways in the @ roseallday.co account. It can be concluded that respondents feel that the @ roseallday.co account always reminds followers about ongoing discounts or giveaways.

\section{Interactive Dimension}

The interactive dimension in this study refers to content that can open lines of communication between brands and their consumers, more precisely between the @ roseallday.co Instagram account and its followers. The respondents mostly gave positive feedback in the question indicator that ensures that the @roseallday.co account displays interactive content. It can be concluded that the @ roseallday.co account displays interactive content for its followers.

\section{Endorsement by Beauty Influencer (X2)}

The endorsement variable in this study acts as the second independent variable or the $\mathrm{X} 2$ variable. Endorsement is one of the most popular sales promotion strategies on social media, especially Instagram. Therefore, the author aims to see the effect of endorsement by beauty influencers on Instagram social media on interest in buying Rose All Day Cosmetics products. The two main attributes of endorsements are credibility and attractiveness. These attributes were then reduced to sub-attributes of the TEARS model, namely Trustworthiness, Expertise, Physical Attractiveness, Respect, and Similarity. The research results in the five dimensions of the endorsement variable derived from the TEARS model sub-attribute were presented below (Shimp \& Andrews, 2013).

\section{Trustworthiness Dimension (Credibility)}

The trustworthiness dimension was derived from the credibility attribute, which is one of the indicators that an influencer must have. Credibility can be determined from the audience's level of trust in the influencer. In this study, the authors measure the level of trust of followers of the @ roseallday.co account on Instagram beauty influencers in collaboration with the Rose All Day Cosmetics brand. Based on the results obtained from the questionnaire, the majority of respondents (more than 81\%) agreed that the beauty influencers provide honest reviews of Rose All Day Cosmetics products. Aside from honesty, beauty influencers must have the ability to convince the audience of the quality of a product. According to the questionnaire results, followers of the @ roseallday.co account thought that beauty influencers on Instagram are indeed capable of convincing them of Rose All Day Cosmetics product quality.

\section{Expertise Dimension}

In addition to the audience's level of trust, an influencer or endorser must also master the technique of communicating a persuasive message so that the audience can well receive it. Followers of the @ roseallday.co account did not agree that beauty influencers must have 
an educational background in makeup. Even so, followers of the @ roseallday.co account still expected beauty influencers to at least have makeup skills.

\section{Similarity Dimension}

An endorser can be a role model for his audience. Thus, it is undeniable that influencers' followers want to imitate their idol's lifestyle, style, and beauty products. This is what is meant by the similarity dimension in the credibility attribute. In this study, it could be seen that Instagram beauty influencers attract followers to choose Rose All Day products by using the similarity factor, which was proven by the respondents' questionnaire.

\section{Physical Attractiveness Dimension}

The attribute that an influencer must have besides credibility is physical attractiveness. In this study, the authors examine the effect of the physical attractiveness of Instagram influencers on the purchase intention of Rose All Day Cosmetics products. The questionnaire results showed that credibility is something that an influencer has to possess. However, physical appearance does not lack importance. More than 300 respondents agreed when asked whether attractive-looking beauty influencers can be trusted more.

\section{Respect Dimension}

The last dimension included in this research questionnaire was the respect dimension which is also a derivative of the attractiveness attribute. An influencer needs to be idolized and has to be respected and valued by the audience. The results of this research questionnaire showed that @ roseallday.co followers thought that every influencer for Rose All Day products always has a good image.

\section{Followers' Purchase Intention}

In buying an item, everyone must go through the interest stage before buying. This study uses the variables of followers' buying interest as the $\mathrm{Y}$ variable or the dependent variable. Four dimensions were used to determine the effect on the buying interest variable in this study: exploratory interest, preferential interest, transactional interest, and referential interest. The following are the results of research based on the four dimensions of buying interest proposed by Duncan (2005).

\section{Explorative Interest Dimension}

The exploratory interest dimension is someone's interest in finding out more about a company's product, service, or sales promotion. Based on the data collected from the questionnaire results in this study, only a few respondents disagreed with the statement that the @ roseallday.co account aroused curiosity about the ongoing promotion. In contrast, the majority of respondents felt that the content of the@roseallday.co account could indeed arouse curiosity about ongoing promotions.

\section{Preferential Interest Dimension}

Preferential interest is consumer preference in choosing a product or brand. A company can change the preferences of consumers or potential customers by offering something 
different from competitors. The results of the research questionnaire showed that the majority of followers of the @ roseallday.co account considered the Rose All Day products superior in the local cosmetic category and is indeed the product of choice.

\section{Transactional Interest Dimension}

Consumers are expected to pass the transactional interest stage in the buying process, namely the interest in buying products or services offered by the company. The questionnaire results showed that respondents agreed that promotional content in discounts and giveaway contests in the @ roseallday.co account increases followers' buying interest.

\section{Referential Interest Dimension}

After going through transactional interest, based on customer satisfaction and the benefits offered by the brand, consumers are also expected to have a referential interest, namely an interest in offering products purchased to friends or relatives as a form of promotional word mouth. According to the questionnaire results, a small number of respondents have no referential interest after seeing promotional content in the @ roseallday.co account. As many as 35 respondents disagreed. The rest of the respondents agreed that promotional content in the @ roseallday.co Instagram account increases the desire to refer products to friends or relatives.

\section{Normality Test}

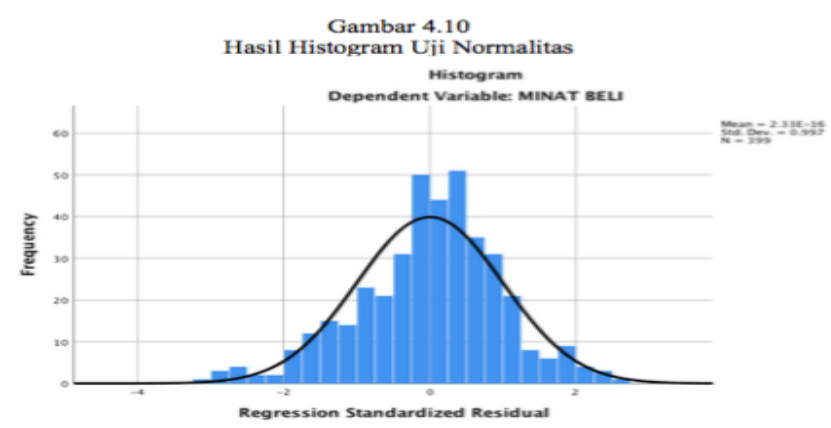

Figure 3. Normality Test Histogram Results

Source: Research Processed Data

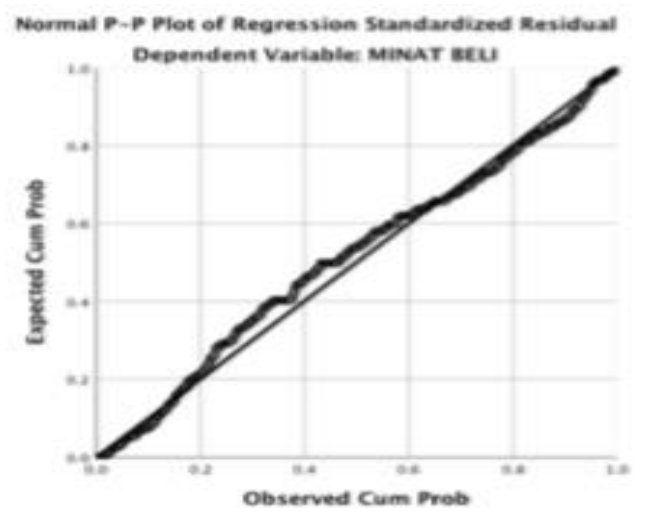

Figure 4. P-Plot Distribution Normality Test Result

Source: Research Processed Data 
The result of the normality test was determined through a histogram and p-plot distribution. Based on the processed data in the form of a histogram in Figure 3, it can be seen that the results of the display resembling a bell can indicate that the data is normally distributed. In addition, Figure 4 shows a normal distribution pattern with a p-plot display that follows a diagonal line, which means no outliers from all of the 398 data acquired.

Multiple Linear Regression Test

After performing the normality test and receiving a normal data distribution, a multiple regression analysis test was carried out.

Table 1. Model Summary Data Result (Determination Coefficient)

\begin{tabular}{|c|c|c|c|c|}
\hline \multicolumn{5}{|c|}{ Model Summary } \\
\hline Model & $\mathrm{R}$ & R Square & $\begin{array}{l}\text { Adjusted R } \\
\text { Square }\end{array}$ & $\begin{array}{l}\text { Std. Error of } \\
\text { the Estimate }\end{array}$ \\
\hline 1 & $.716^{\mathrm{a}}$ & .513 & .510 & 1.68973 \\
\hline
\end{tabular}

Source: Data Processed

Based on Table 1, the $\mathrm{R}$ value is 0.716 , indicating a strong relationship between variables $\mathrm{X} 1$ and X2 simultaneously on the Y variable. Furthermore, there is an R Square value of 0.513 or $51.3 \%$. It means that the variables $\mathrm{X} 1$ and $\mathrm{X} 2$ simultaneously influences variable $\mathrm{Y}$ by $51.3 \%$. The remaining $48.7 \%$ is influenced by other variables outside the regression equation in this study.

Table 2. Anova Data Result (F Statistic Test)

\begin{tabular}{|c|c|c|c|c|c|}
\hline \multicolumn{6}{|c|}{ ANOVA $^{a}$} \\
\hline Model & $\begin{array}{c}\text { Sum of } \\
\text { Squares }\end{array}$ & df & $\begin{array}{c}\text { Mean } \\
\text { Square }\end{array}$ & $F$ & Sig. \\
\hline Regression & 1189.761 & 2 & 594.880 & 208.351 & $.000^{\circ}$ \\
\hline Residual & 1130.650 & 396 & 2.855 & & \\
\hline Total & 2320.411 & 398 & & & \\
\hline
\end{tabular}

\section{Source: Data Processed}

In table 2, it can be seen that the calculated f value was 208, $351>\mathrm{f}$ table 3.0 . Thus, it could be concluded that the attractiveness of sales promotion messages (X1) and endorsements (X2) simultaneously affects the $\mathrm{Y}$ variable in this study. In addition, with a significance value of 0.000 , which is less than 0.05 , it indicates that the null hypothesis is rejected and the alternative hypothesis is accepted. The formula for finding the F table was as follows. 


$$
\text { F table }=(k ; n-k)
$$

$\mathrm{k}=$ number of independent variables $(\mathrm{X})$

$\mathrm{n}=$ number of respondents/ samples

$$
\begin{array}{r}
f \text { table }=(2 ; 398-2) \\
=(2 ; 396)=3,00
\end{array}
$$

\begin{tabular}{|c|c|c|c|c|c|c|}
\hline \multicolumn{7}{|c|}{ Coefficients $^{\mathrm{a}}$} \\
\hline \multirow{2}{*}{\multicolumn{2}{|c|}{ Model }} & \multicolumn{2}{|c|}{$\begin{array}{l}\text { Unstandardized } \\
\text { Coefficients }\end{array}$} & \multirow{2}{*}{$\begin{array}{l}\text { Standardized } \\
\text { Coefficients } \\
\text { Beta }\end{array}$} & \multirow[b]{2}{*}{$t$} & \multirow[b]{2}{*}{ Sig. } \\
\hline & & B & Std. Error & & & \\
\hline \multirow[t]{3}{*}{1} & (Constant) & 1.642 & .749 & & 2.192 & .029 \\
\hline & $\begin{array}{l}\text { DAYA TARIK } \\
\text { PESAN }\end{array}$ & .345 & .028 & .485 & 12.167 & .000 \\
\hline & ENDORSEMENT & .262 & .030 & .344 & 8.620 & .000 \\
\hline
\end{tabular}

Table 3. Multiple Regression Test Data Result (T Statistic Test)

Source: Data Processed

In table 3 , it can be seen that the constant value (a) is 1.642 , the attractiveness value of sales promotion messages (X1) is 0.345 , and the endorsement value (X2) is 0.262 . Then the regression equation can be made, namely $\mathrm{Y}=1.642+0.345 \mathrm{X} 1+0.262 \mathrm{X} 2$. The constant 1.642 indicates that if the attractiveness of sales promotion messages and endorsements is 0 , then the value of buying interest is 1.642. If the coefficient of determination of the attractiveness of the sales promotion message increases, then the constant value of buying interest increases by 0.345 with the assumption that there is no additional value (constant) of endorsement. If the coefficient of endorsement determination increases, then the constant value of buying interest increases by 0.262 with the assumption that there is no increase in the value (constant) of the attractiveness variable of sales promotion messages.

The t-test was conducted to partially determine the effect of two or more independent variables on the dependent variable. In this study, the t-test was conducted to determine the effect of the attractiveness of the sales promotion message on the buying interest variable and the effect of the endorsement variable on the buying interest variable. Two kinds of tests can be done: looking at the significant value and comparing the t-count value with the t-table value. The formula to find out the $t$ table was:

$$
\begin{gathered}
\mathrm{t}=/ 2 ; \mathrm{n}-\mathrm{k}-1 \\
\mathrm{t}=((0.05) / 2 ; 398-2-1) \\
\mathrm{t}=(0.025 ; 395) \\
\mathrm{t}=1.980
\end{gathered}
$$


In table 3 , it can be seen that the value of sig $0.000<0.05$. Therefore, it can be concluded that Hal is accepted, which means there is a partial effect of the attractiveness of sales promotion messages on buying interest. It is known that the value of $t$ count is $8620>t$ table 1,980 and sig. for the effect of endorsement (X2) on buying interest (Y) is $0.000<0.0$. Thus, it can be concluded that $\mathrm{Ha} 2$ is accepted; namely, there is an effect of endorsement by beauty influencers on buying interest of followers of Instagram account @ roseallday.co.

\section{DISCUSSION}

Based on the data processing results, it can be concluded that there is a simultaneous influence between the attractiveness of the sales promotion message for the @ roseallday.co account and endorsements by beauty influencers on followers' buying interest. Both variables simultaneously affected $51.53 \%$ of buying interest. In comparison, the remaining $48.7 \%$ was influenced by other variables or factors outside of this study. Many social media marketing strategies can be done. Coupled with the creativity of young people who are used optimally to create the most engaging interactive campaigns, advertisements, and content, the competition in social media marketing strategies is getting tougher (Susilo \& Putranto, 2018; Yunus et al. 2019).

In the buying decision process, consumers must pass two routes. These routes include the central route, which is a way of processing critically and rationally in capturing the content or message received, and the peripheral route, namely the emotional side of consumers in capturing a new message or information (Griffin et al., 2015). The content in the Rose All Day Cosmetics Instagram account that features sales promotions such as discounts is more attractive to consumers who make purchasing decisions through the central route. Meanwhile, non-monetary content such as giveaways and donations by purchase during the COVID-19 pandemic is more attractive to consumers who take the peripheral route in purchasing decisions ( Susilo et al. 2021; Susilo \& Putranto, 2021).

Both monetary and non-monetary sales promotion content Ogden-Barnes \& Minahan (2015) turned out to have an important role in the success of social media marketing strategies. Duncan's theory supports this, which states that eight dimensions can convey an effective sales promotion message. However, only six dimensions are relevant for this research, namely the generic, pre-emptive, and informational dimensions that support the central route in decision making and the reminder, interactive dimension that supports decision making via the peripheral route.

The Instagram content by Rose All Day Cosmetics showed the dimensions of a generic message, namely photos and product videos that show the texture, size, packaging, and directions to use products. Meanwhile, the pre-emptive dimension was applied by showing various photos from various cosmetic and skincare series. Meanwhile, the informational content displayed by the Rose All Day account was information about discounts or ongoing giveaway contests. The content also included a reminder dimension because it reminds followers of ongoing promotional activities. Not only informative, but Rose All Day's Instagram content also shows the emotional dimension in contents that persuade consumers to buy products. An example that the Rose All Day Cosmetics account does is by highlighting the giveaway content and the COVID-19 donation program. 
In addition, in "Social Media Strategy: Marketing, Advertising, And Public Relations In The Consumer Revolution," Quesenberry advises companies to maximize the use of influencer marketing strategies or endorsements. Meanwhile, the latest endorsement trend is to use a micro-influencer marketing strategy (Quesenberry, 2020). This marketing strategy has been carried out by Rose All Day Cosmetics in their Instagram account by displaying every micro-influencer who uploads a photo of themselves when using Rose All Day products and using the hashtag \#WearRoseAndSlay.

This study compiled an indicator of the endorsement variable from the TEARS model attribute by Shimp \& Andrews (2013), which explains that an influencer must have five main attributes: trustworthiness, expertise, assertiveness, respect, and similarity. Based on research results, the endorsement strategy used in the Rose All day Cosmetics Instagram account has fulfilled all of the TEARS requirements. It means that they have done well with this marketing activity. It can also be concluded that followers go through central and peripheral decision-making routes while processing endorsed messages on the Rose All Day Instagram account.

This study uses the purchase interest theory by Ferdinand (2014), which includes exploratory, preferential, transactional and referential dimensions to measure the buying interest variable. Research result shows that the Rose All Day Instagram account served intriguing promotional contents to increases followers' purchase interest. In addition, the followers would mostly go through a peripheral decision-making route instead of the central route. Evidently, the followers' purchase intention was more easily triggered by emotional aspects than rational ones. However, the followers go through a slight rational side, which is the monetary sales promotion content. As for the endorsement content, the followers are likely to follow their emotional instincts.

Due to competitors' Instagram social media accounts (De Leon et al. 2020; Leeraphong \& Papasratorn, 2018; Susilo et al. 2019), it seems that Rose All Day's Instagram account does not highlight the brand's characteristics enough. Therefore, the Rose All Day should increase content that shows the brand's characteristics, such as Q and A sessions with the company's founders (Tiffany, Samantha, and Cindy) so that followers familiarize themselves with the women behind the brand and have a closer relationship with the brand.

Another strategy that can be utilized by the Rose All Day is the brand's tagline, namely "Clean, Halal, and Cruelty-Free". The tagline can be implemented in the contents, for example, by showing the process of making the Rose All Day products and the halal ingredients used. Therefore, to increase Instagram's social media marketing strategy (Quesenberry, 2020; Ritzer et al., 2012; Shimp \& Andrews, 2013; Yunus et al., 2019), Rose All Day must diversify its content. The result implies that brands should pay attention to promotional and monetary aspects and emotional and non-monetary aspects. It means that Instagram promotion contents should display the products being sold and build the brand's characteristics and identity.

Another marketing factor that could be used includes green marketing. Based on the research result, Rose All Day can expand its audience reach by using rapidly growing social media, such as TikTok. Brands must consider the TikTok phenomenon, which has 698 
million users worldwide at the beginning of 2021 (datareportal, 2021), which has been increasing by $20 \%$ during the Covid-19 pandemic (katadata, 2020).

Furthermore, due to the success of the endorsement marketing strategy by beauty influencers on Instagram, Rose All Day Cosmetics must continue to follow the development of influencers, especially in micro-influencers (Quesenberry, 2020). Most micro-influencers have an audience with an age range of 17-25 years old, which is a profitable market share, according to Kotler et al. (2017). Indeed, young people are early adopters and trendsetters who are more easily influenced and open to new experiences. This trait is needed and can be utilized by Rose All Day to expand their target market based on the willingness of young people to try new things.

\section{CONCLUSION}

This research was intended to determine the effect of attractiveness on beauty influencers' sales promotion messages and endorsements on followers' buying interest. Several conclusions can be drawn to answer the main problem in this study based on the data analysis. The conclusions is that there is an effect of the attractiveness of sales promotion messages on Instagram @ roseallday.co and endorsement by beauty influencers simultaneously on the buying interest of followers by $51.3 \%$. In comparison, $48.7 \%$ is influenced by factors outside of this study. The constant states that if the attractiveness of sales promotion messages and endorsements by beauty influencers is 0 , then the value of buying interest is 1,642 . If the coefficient of determination of the attractiveness of the message increases, then the constant value of buying interest increases by 0.345 with the assumption that there is no additional packaging value. If the value of the endorsement coefficient increases, then the constant value of buying interest increases by 0.262 with the assumption that there is no additional message attractiveness value. The attractiveness of Rose All Day Cosmetics Instagram sales promotion messages and endorsements by beauty influencers partially influences followers' buying interest.

From the research results, it can be concluded that Ho is rejected and $\mathrm{Ha}$ is accepted. Therefore, this study shows an effect on the attractiveness of sales promotion messages on the @ roseallday.co account and endorsements by beauty influencers simultaneously on the variable of followers' buying interest. This proves that in carrying out social media marketing strategies, Rose All Day must combine two strategies at once by looking at the latest trends to produce effective results. This can be done by monitoring the competitors' strategies and implementing the same strategy, but with different implementations and adapted to the brand identity. Based on the conclusion, it is suggested that future research examine other factors that influence the purchase interest of Instagram followers @ roseallday.co, both from marketing or outside marketing.

\section{ACKNOWLEDGMENT}

The author expresses their gratitude for the research support from Universitas Multimedia Nusantara. 


\section{REFERENCES}

Belch, G., \& Belch, M. (2017). Advertising and promotion: An integrated marketing communications perspective. The McGraw- Hill.

Butow, E., Herman, J., Liu, S., Robinson, A., \& Allton, M. (2020). Ultimate Guide to Social Media Marketing. Entrepreneur Press.

De Leon, M. V., Atienza, R. P., \& Susilo, D. (2020). Influence of self-service technology (SST) service quality dimensions as a second-order factor on perceived value and customer satisfaction in a mobile banking application. Cogent Business \& Management, 7(1). https://doi.org/10.1080/23311975.2020.1794241

Decker, A. (2017). Instagram Marketing.

Duncan, T. (2005). Principles of Advertising \& IMC, 2nd edn. Taylor \& Francis.

Ferdinand, A. (2014). Metode Penelitian Manajemen. Badan Penerbit Universitas Diponegoro.

Geraldine. (2019). Pengaruh Daya Tarik Konten Social Media Marketing Instagram Buku NKCTHI (Nanti Kita Cerita tentang Hari ini) terhadap Niat Beli Konsumen. Universitas Multimedia Nusantara.

Ghozali, I. (2013). Aplikasi Analisis Multivariate Dengan Program IBM SPSS 21 Update PLS Regresi. Semarang: Badan Penerbit Universitas Diponegoro. Information Technology, 2(2).

Griffin, E., Ledbetter, A., \& Sparks, G. (2015). Communication Privacy Management Theory of Sandra Petronio. New York, NY: McGraw-Hill Education.

Gunelius, S. (2010). 30-minute social media marketing: Step-by-step techniques to spread the word about your business: Social media marketing in 30 minutes a day. McGraw Hill Professional.

Kemenperin.go.id. (2018). Industri Kosmetik Nasional Tumbuh $20 \%$.

Kemp, S. (2021). Digital 2021: Indonesia.

Kotler, P., Kartajaya, H., \& Setiawan, I. (2017). Marketing 4.0. Moving from Traditional to Digital, Published by John Wiley\&Sons (Vol. 32). Inc., Hoboken, New Jersey.

Kriyantono, R. (2014). Teknik Praktis Riset Komunikasi. Prenada Media.

Leeraphong, A., \& Papasratorn, B. (2018). S-Commerce Transactions and Business Models in Southeast Asia: A Case Study in Thailand. KnE Social Sciences. https://doi.org/10.18502/kss.v3i1.1397

Ogden-Barnes, S., \& Minahan, S. (2015). Sales promotion decision making: concepts, principles, and practice. Business Expert Press.

Panuju, R., Susilo, D., \& Sugihartati, R. (2018). A Strategy for Competitive Broadcasting Radio Community Networking in Tulungagung, Indonesia. https://doi.org/10.5220/0007331504670472

Patricia, V. (2018). The Effect of Endorsement by Beauty Influencers on Purchase Intention of Maybelline New York Products (Survey in Tangerang City Area). Universitas Multimedia Nusantara.

Peter, J., Olson, J., \& Grunert, K. (1999). Consumer behaviour and marketing strategy. McGraw-hill London, UK:

Petty, R., Cacioppo, J., \& Berkowitz, L. (1986). The elaboration likelihood model of persuasion. Advances in Experimental Social Psychology, 19, 123-205.

Quesenberry, K. (2020). Social media strategy: Marketing, advertising, and public relations in the consumer revolution. Rowman \& Littlefield Publishers.

Ritzer, G., Dean, P., \& Jurgenson, N. (2012). The Coming of Age of the Prosumer. American Behavioral Scientist. https://doi.org/10.1177/0002764211429368

Riyadi, S., Susilo, D., Sufa, S. A., \& Dwi Putranto, T. (2019). Digital marketing strategies to 
boost tourism economy: A case study of atlantis land Surabaya. Humanities and Social Sciences Reviews. https://doi.org/10.18510/hssr.2019.7553

Shimp, T., \& Andrews, J. (2013). Advertising, promotion, and other aspects of integrated marketing communications. South-Western College Pub.

Sugiyono. (2016). metodologi penelitian kuantitatif kualitatif dan R \& D. In Bandung: Alfabeta. https://doi.org/10.1164/rccm.200409-1267OC

Sugiyono. (2018). Metode Penelitian Kuantitatif, Kualitatif, Dan R\&D. Penerbit CV. Alfabeta.

Susilo, D., Prabowo, T. L., \& Putranto, T. D. (2019). Communicating secure based feeling: Content analysis on indonesian police official account. International Journal of Engineering and Advanced Technology, 8(6), 2541-2543. https://doi.org/10.35940/ijeat.F8377.088619

Susilo, D. (2021a). AKSI-AKSI WARGANET PADA BERITA DARING: Cabaran pada Studi Posfeminisme dan Politik. Airlangga University Press.

Susilo, D. (2021b). Analisis wacana kritis van dijk: sebuah model dan tinjauan kritis pada media daring. Unitomo Press.

Susilo, D, \& Putranto, T. D. (2018). Indonesian Youth on Social Media: Study on Content Analysis. https://doi.org/10.2991/sshr-17.2018.15

Susilo, D, \& Putranto, T. D. (2021). Content analysis of instagram posts related to the performance of the national search and rescue agency in early 2021. Jurnal Komunikasi Profesional, 5(1).

Susilo, D., Putranto, T. D., \& Navarro, C. J. S. (2021). 9 Performance of Indonesian Ministry of Health in Overcoming Hoax About Vaccination Amid the COVID-19 Pandemic on Social Media. Nyimak: Journal of Communication, 5(1), 151-166.

Yunus, E., Susilo, D., Riyadi, S., Indrasari, M., \& Putranto, T. D. (2019). The effectiveness marketing strategy for ride-sharing transportation: intersecting social media, technology, and innovation. Entrepreneurship and Sustainability Issues, 7(2), 14241434. https://doi.org/10.9770/jesi.2019.7.2(44) 